\title{
STUDI KANDUNGAN LOGAM BERAT PADA KERANG LOKAN (Geloina erosa) DI PERAIRAN ACEH BARAT
}

\author{
Nabila Ukhty ${ }^{1 *}$, Hayatun Nufus ${ }^{2}$, Anhar Rozi ${ }^{1}$, Ikhsanul Khairi ${ }^{1}$ \\ ${ }^{1}$ Program Studi Perikanan, Fakultas Perikanan dan Ilmu Kelautan, Universitas Teuku Umar, Aceh Barat \\ ${ }^{2}$ Program Studi Ilmu Kelautan, Fakultas Perikanan dan Ilmu Kelautan, Universitas Teuku Umar, Aceh \\ Barat \\ Korespondensi : nabilaukhty@utu.ac.id \\ Diterima: 14 November 2019/Disetujui: 30 April 2020
}

Cara sitasi: Ukhty N, Nufus H, Rozi A, Khairi I. 2020. Studi kandungan logam berat pada kerang lokan (Geloina erosa). Jurnal Pengolahan Hasil Perikanan Indonesia. 23(1): 77-85.

\begin{abstract}
Abstrak
Pesatnya pertumbuhan industri di wilayah pesisir Aceh Barat diduga menjadi sumber pencemaran logam berat di perairan dan terakumulasi pada biota laut, salah satunya yaitu kerang lokan (Geloina erosa). Penelitian ini bertujuan untuk menganalisis kandungan logam berat $\mathrm{Hg}, \mathrm{Cd}, \mathrm{Pb}, \mathrm{Cu}, \mathrm{As}$, dan $\mathrm{Zn}$ pada kerang lokan mentah dan rebus, serta menentukan batas toleransi konsumsi kerang lokan yang mengandung logam berat. Pengambilan sampel kerang lokan dilakukan di 3 stasiun, yaitu perairan Peunaga Rayeuk, Ujong Baroh, dan Kuala Bubon. Sampel dikelompokkan menjadi dua perlakuan, yaitu P1 (mentah) dan P2 (rebus). Analisis kandungan logam berat menggunakan Atomic Absorbtion Spectrophotometry (AAS). Hasil analisis kandungan logam Hg pada stasiun 2 yaitu P1 13,2754 mg/kg dan P2 sebesar 12,5491 mg/kg, pada stasiun 3 yaitu P1 1,2418 mg/kg dan P2 0,1956 mg/kg. Kandungan logam Cd hanya terdeteksi pada stasiun 2 yaitu P1 0,0058 mg/kg. Kandungan logam Cu pada stasiun 1 yaitu P1 sebesar 0,0686 mg/kg dan P2 0,0541 mg/kg, pada stasiun 2 yaitu P1 0,1381 mg/kg dan P2 sebesar 0,0999 mg/kg, dan pada stasiun 3 yaitu P1 sebesar 0,1062 mg/kg dan P2 sebesar $0.022 \mathrm{mg} / \mathrm{kg}$. Kandungan logam Zn pada stasiun 1 yaitu P1 $3,4883 \mathrm{mg} / \mathrm{kg}$ dan P2 s 3,3229 mg/kg, pada stasiun 2 yaitu P1 sebesar 2,7643 dan P2 sebesar 2,6225 mg/kg, dan pada stasiun 3 yaitu P1 4,2511 mg/kg dan P2 2,8687 mg/kg. Batas maksimum berat daging kerang lokan yang boleh dikonsumsi untuk orang dewasa $(50 \mathrm{~kg} b$ b) yaitu $0,131 \mathrm{~kg}$ daging per minggu.
\end{abstract}

Kata Kunci : absorption spectrophotomer, Aceh Barat, Geloina erosa, logam berat

\section{Study of Heavy Metal Content in Locan Clam (Geloina Erosa) Muscle in West Aceh Waters}

\begin{abstract}
The rapid industrial growth in the coastal area of West Aceh was thought to be a source of heavy metal pollution in the waters and accumulated in marine biota, such as lokan clam (Geloina erosa). The aims of this study are to analyze the content of heavy metals $\mathrm{Hg}, \mathrm{Cd}, \mathrm{Pb}, \mathrm{Cu}$, As and $\mathrm{Zn}$ in raw and boiled lokan clam, and determine the tolerance limit to consume lokan clam containing the heavy metals. Samples were collected at 3 stations, namely Peunaga Rayeuk, Ujong Baroh, and Kuala Bubon. Samples were grouped into two treatments, namely P1 (raw) and P2 (boiled). Heavy metal analysis used Atomic Absorbtion Spectrophotometry (AAS). The results of the analysis of $\mathrm{Hg}$ metal content at station 2 namely P1 was $13.2754 \mathrm{mg} / \mathrm{kg}$ and P2 was $12.5491 \mathrm{mg} / \mathrm{kg}$, at station 3 namely P1 was $1.2418 \mathrm{mg} / \mathrm{kg}$ and P2 was $0.1956 \mathrm{mg} /$ $\mathrm{kg}$. The Cd metal content was only detected at station 2 namely P1 was $0.0058 \mathrm{mg} / \mathrm{kg}$. Cu metal content at station 1 namely P1 was $0.0686 \mathrm{mg} / \mathrm{kg}$ and P2 was $0.0541 \mathrm{mg} / \mathrm{kg}$, at station 2 namely P1 awas $0.1381 \mathrm{mg} / \mathrm{kg}$ and P2 was $0.0999 \mathrm{mg} / \mathrm{kg}$, and at station 3 namely P1 was $0.1062 \mathrm{mg} / \mathrm{kg}$ and P2 was $0.022 \mathrm{mg} / \mathrm{kg}$. The metal content of $\mathrm{Zn}$ at station 1 namely P1 was $3.4883 \mathrm{mg} / \mathrm{kg}$ and P2 was $3.3229 \mathrm{mg} / \mathrm{kg}$, at station 2 namely P1 was 2.7643 and P2 was $2.6225 \mathrm{mg} / \mathrm{kg}$, and at station 3 namely P1 was $4.2511 \mathrm{mg} / \mathrm{kg}$ and P2 was $2.8687 \mathrm{mg} /$ $\mathrm{kg}$. The maximum weight limit of lokan clam muscle for adults ( $50 \mathrm{~kg} \mathrm{bb})$ was $0.131 \mathrm{~kg}$ muscle per week.
\end{abstract}

Keywords : Geloina erosa, heavy metal, spectrophotomer absorption, West Aceh 


\section{PENDAHULUAN}

Kabupaten Aceh Barat terletak di pesisir barat Provinsi Aceh tepatnya di perairan Barat Selatan dengan panjang garis pantai $54,84 \mathrm{~km}$ dan luas wilayah perairan lautnya mencapai 37,18/957,38 km2 (DKP Aceh Barat 2017). Kawasan pesisir Aceh Barat termasuk kawasan padat penduduk, sehingga mendorong meningkatnya aktivitas manusia baik itu kegiatan rumah tangga, industri maupun pertanian. Peningkatan tersebut berdampak terhadap lingkungan perairan, hal ini dapat dilihat sebagian besar hasil samping dari aktivitas manusia dibuang ke perairan. Kondisi inilah yang memberikan pengaruh terhadap penurunan kualitas air di wilayah perairan Aceh Barat.

Kualitas air memengaruhi biota laut yang hidup di lokasi perairan tersebut, biota laut tersebut sebagian besar menjadi sumber pangan bagi masyarakat pesisir. Kebersihan lingkungan perairan sangat ditentukan oleh buangan limbah, baik itu dalam bentuk limbah organik, anorganik dan limbah tersuspensi (Palar 2004). Terdapat beberapa unit industri yang terletak di wilayah perairan Aceh Barat, yaitu industri pengolahan batu bara, industri pembangkit listrik tenaga uap (PLTU), industri penambangan emas, limbah buangan kapal, dan juga limbah rumah tangga. Pembuangan limbah yang tidak terkontrol ini dikhawatirkan dapat mencemari perairan Aceh Barat yang merupakan pusat sumber pangan dan mata pencaharian masyarakat. limbah yang tergolong berbahaya yaitu limbah yang bersifat anorganik, yaitu logam berat.

Logam berat merupakan salah satu jenis bahan pencemar pada lingkungan. Beberapa dari unsur logam tersebut tergolong dalam logam berbahaya, di antaranya Arsen (As), Timbel (Pb), Merkuri (Hg) dan Kadmium (Cd). Logam-logam tersebut dapat membahayakan tubuh manusia jika terakumulasi di dalam tubuh melebihi ambang batas keamanan konsumsi. Kelebihan tersebut dapat mengakibatkan penghambatan sistem pembentukan hemoglobin $(\mathrm{Hb})$ di dalam tubuh (Palar 2004).

Kerang lokan (Geloina erosa) merupakan salah satu biota hasil perairan yang banyak ditemukan di kawasan perairan Aceh Barat dan menjadi komoditi yang banyak dimanfaatkan oleh masyarakat Aceh barat sebagai konsumsi harian. Potensi kerang lokan sebagai sumber protein hewani juga sangat baik, dengan kadar protein kerang lokan 7,06 - 16,87\% dalam 100 gram bahan (Irawan et al. 2015).

Seiring meningkatnya aktivitas mahasiswa di kawasan pesisir dapat menyebabkan kandungan logam berat meningkat dan akan terakumulasi dalam tubuh organisme di wilayah perairan tersebut (Setiawan 2013). Pengendapan logam berat akan terakumulasi di dalam tubuh kerang lokan (Geloina erosa) karena cara makan kerang yang bersifat filter feeder. Beberapa peneliti telah menginformasikan kandungan logam berat pada perairan Aceh Barat, diantaranya Edwarsyah (2017) menyatakan bahwa sampel air dari estuaria Krueng Cangkoi, Aceh Barat mengandung logam berat $\mathrm{Cd}$ yaitu 0,14 $\mathrm{mg} / \mathrm{L}$ dan $\mathrm{Fe}$ sebesar 0,56 mg/L. Warni et al. (2017) menyatakan bahwa sedimen yang diambil dari perairan kawasan pelabuhan jetty Meulaboh, Aceh Barat mengandung logam berat $\mathrm{Pb} 112,76 \mathrm{mg} / \mathrm{L}, \mathrm{Cu} 288,7 \mathrm{mg} / \mathrm{L}$, dan logam Mn yang telah melewati ambang batas baku mutu. Pada daging kerang Anodonta Sp. dari kawasan hilir Sub Das Krueng Meureubo, Aceh Barat mengandung logam berat mekuri (Hg) sebesar 0,074-0,304 mg/kg (Munandar dan Alamsyah 2016). Kondisi inilah yang mendorong peneliti untuk melakukan penelitian mengenai analisis kandungan logam berat $(\mathrm{Pb}, \mathrm{Cu}, \mathrm{Hg}$, $\mathrm{As}$, dan $\mathrm{Cd})$ pada daging kerang lokan dan serta menganalisis batas aman kerang lokan (Geloina erosa) dari perairan Aceh Barat untuk dikonsumsi berdasarkan kandungan logam berat.

Penelitian ini bertujuan untuk menganalisis kandungan logam berat $\mathrm{Hg}, \mathrm{Cd}$, $\mathrm{Pb}, \mathrm{Cu}$, As dan $\mathrm{Zn}$ pada kerang lokan mentah dan rebus, serta menentukan batas toleransi konsumsi kerang lokan yang mengandung logam berat.

\section{METODE PENELITIAN Bahan dan Alat}

Sampel dalam penelitian ini adalah kerang lokan (Geloina erosa). Bahan kimia 
yang dipakai dalam penelitian ini yaitu standar logam $\mathrm{Pb}, \mathrm{Cu}, \mathrm{Hg}, \mathrm{Zn}$, dan $\mathrm{Cd}$, $\mathrm{HNO}_{3}$, akuabides, $\mathrm{NaOH}$, HCl.Peralatan yang digunakan antara lain Atomic Absorption Spectrophotometer (AAS) merk (Shimadzu AA 7000), neraca listrik (Mettler AE 204), krus porselen, hot plate, oven, labu ukur, plastik sampel, botol sampel, kamera digital, spatula, gelas kimia, kaca arloji, kertas saring 40 (whatman), water bath, dan timbangan digital

\section{Metode penelitian}

Penelitian ini telah dilaksanakan pada bulan Februari 2019. Penelitian dilakukan di Laboratorium Baristand Industri Banda Aceh. Tahapan penelitian terdiri dari empat tahapan, yaitu pengambilan sampel kerang lokan, preparasi kerang lokan menjadi dua perlakuan yaitu P1 (mentah) dan P2 (rebus), Uji kandungan logam berat, dan analisis data. Penelitian ini menggunakan metode studi kasus, dengan pemilihan lokasi sampling berdasarkan Purposive Sampling. Tiga stasiun pengambilan sampel yaitu perairan Peunaga Rayeuk, Kecamatan Mereubo) (stasiun 1), Perairan Ujong Baroh, Kecamatan Johan Pahlawan (Stasiun 2), dan Perairan Kuala Bubon, Kecamatan Samatiga (Stasiun 3). Lokasi pengambilan sampel dapat dilihat pada Figure 1.
Dasar pengambilan sampel di tiga lokasi berbeda karena:

1.Peunaga Rayeuk: merupakan kawasan Perairan di Aceh Barat padat penduduk yang sebagian besar terdiri dari wilayah persawahan yang terhubung langsung dengan sungai Meurebo. Selain itu perairan ini juga berdekatan dengan kawasan industri pertambangan (batu bara).

2. Ujong Baroh: merupakan kawasan Perairan di Aceh Barat dengan aktivitas perkapalan penangkapan ikan, pelabuhan kapal antar Kabupaten (Siemeulu-Aceh Barat), dan kawasan padat penduduk.

3. Kuala Bubon: merupakan kawasan Perairan di Aceh Barat dengan aktivitas perkapalan penangkapan ikan dan kawasan industri rumah tangga.

\section{Perlakuan sampel}

Sampel kerang lokan sebanyak $2 \mathrm{~kg}$ di setiap lokasi diambil kemudian dimasukkan ke dalam plastik yang sudah ditambahkan air dan telah dibuat lubang-lubang kecil pada plastik sampel untuk memberikan oksigen pada sampel kerang. Preparasi sampel dilakukan dengan cara memisahkan cangkang dan daging kerang, kemudian sampel dibagi menjadi dua perlakuan yang berbeda yaitu kerang mentah (P1) sebaanyak $1 \mathrm{~kg}$ dan kerang rebus (P2) sebanyak $1 \mathrm{~kg}$. Sampel kerang

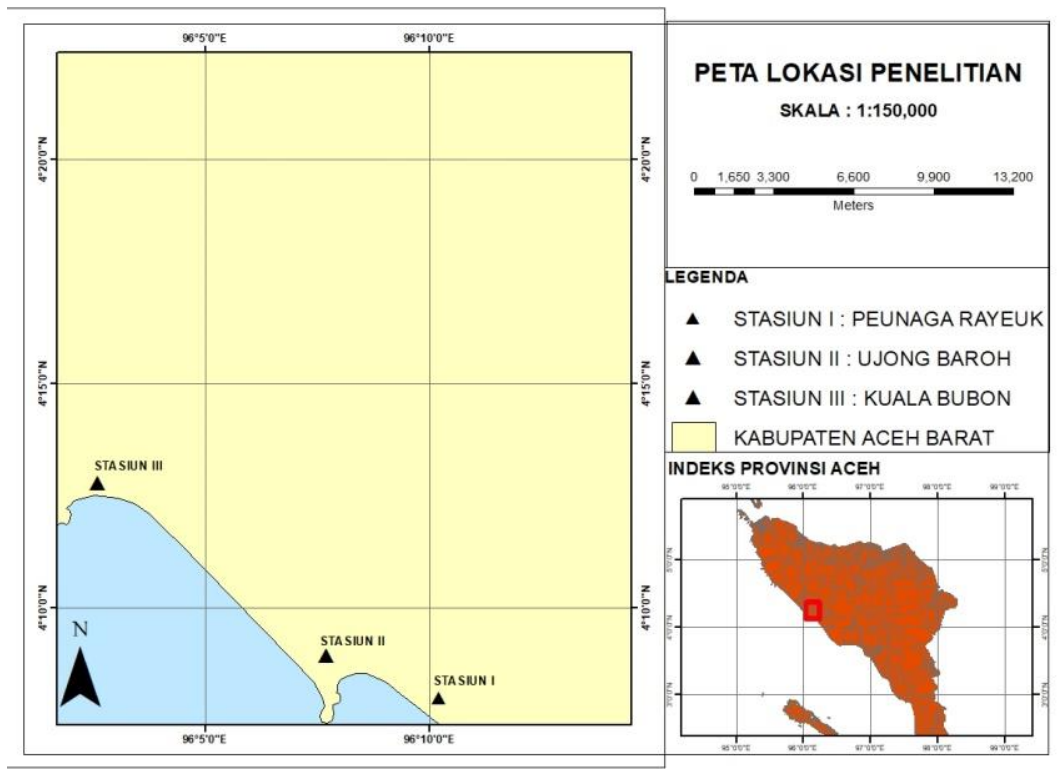

Figure 1. Map of Sampling Locations 
kemudian dianalisis kandungan logam berat dengan menggunakan Atomic Absorption Spectrophotometer (AAS)

\section{Analisis logam berat}

Pengukuran logam berat $\mathrm{Cd}, \mathrm{Pb}, \mathrm{Cu}$ pada daging kerang lokan (P1: mentah dan P2: rebus) dilakukan dengan menambahkan $5 \mathrm{ml} \mathrm{HNO}_{3}$ pekat, kemudian dipanaskan pada suhu $60-70{ }^{\circ} \mathrm{C}$ selama 47 menit sampai larutan sampel menjadi jernih. Pengukuran logam berat $\mathrm{Hg}$ pada daging kerang lokan (P1: mentah dan P2: rebus) dilakukan dengan penambahan $5 \mathrm{ml}$ asam sulfat terlebih dahulu, didiamkan selama 5 menit. Setelah itu, sampel ditambahkan $5 \mathrm{ml} \mathrm{HNO}_{3}$ pekat dan didiamkan selama 24 jam. Semua sampel ditambahkan $150 \mathrm{ml}$ akuades dan diamkan selama 5 menit, setelah itu dilakukan penambahan $\mathrm{KMnO}_{4}$ sebanyak 2 gr sampai warna sampel berubah menjadi lebih pekat dan didiamkan dilemari asam selama 2 jam. Sampel siap diukur dengan AAS (Atomic Absorbtion Spectrophotometry) menggunakan nyala udara-asetilen (APHA 1992).

\section{Analisis data}

Data yang dianalisis pada penelitian ini merupakan data kandungan logam berat yang diperoleh dari alat AAS . Data tersebut ditampilkan dalam bentuk diagram batang yang menentukan nilai absorbansi dan nilai konsentrasi logam berat (Supriatno dan Lelifajri 2009). Rumus yang digunakan untuk menentukan kandungan Logam berat adalah:

$\operatorname{Kadar} \operatorname{Logam}(\mathbf{m g} / \mathbf{k g})=\frac{\operatorname{Creg} \times \mathrm{P} \times \mathrm{V}}{G}$

Keterangan :

Creg $=$ Konsentrasi terbaca $(\mathrm{mg} / \mathrm{L})$
$\mathrm{P} \quad=$ Faktor Pengenceran

$\mathrm{V}=$ Volume larutan sampel (L)

$\mathrm{G} \quad=$ Berat sampel $(\mathrm{kg})$

Batas maksimum konsentrasi dari bahan pangan terkonsentrasi logam berat yang boleh dikonsumsi per minggu (Maksimum Weekly Intake)dapatdilihat pada Table 1, angka ambang batas yang digunakan yaitu diterbitkan oleh organisasi dan lembaga pangan internasional World Health Organitation (WHO) dan Joint FAO/WHO Expert Committee on Food Additive (JEFCA). Perhitungan maximum weekly intake menggunakan rumus :

$$
\text { MWI (g) = Berat badan }{ }^{\text {a) }} \times \text { PTWI }{ }^{\text {b) }}
$$

Keterangan :

a): Untuk asumsi berat badan sebesar $50 \mathrm{~kg}$ b):PTWI Provisional Tolerable Weekly Intake (angka toleransi batas maksimum per minggu) yang dikeluarkan lembaga pangan terkait dalam satuan $\mu \mathrm{g} / \mathrm{kg}$.

Nilai maksimum weekly intake (MWI) dan konsentrasi logam berat yang terkandung di dalam kerang lokan digunakan untuk menghitung berat maksimal daging kerang yang dapat dikonsumsi setiap minggunya. Untuk mengetahui batasan berat tersebut, maka nilai maksimum tolerable intake (MTI) dihitung dengan perumusan (Turkemen et al. 2008), yaitu:

$$
\text { MTI }=\text { MWI } / \text { Ct }
$$

Keterangan :

MWI = Maximum Weekly Intake ( $\mu \mathrm{g}$ untuk orang dengan berat badan $60 \mathrm{~kg}$ per minggu) $\mathrm{Ct}=$ Konsentrasi logam berat yang ditemukan di dalam jaringan lunak kerang ( $\mu g . g-1)$.

Table 1 Maximum Tolerance Limit Consumption Per Week

\begin{tabular}{cc}
\hline Heavy Metal & PTWI $(\mu \mathrm{g} / \mathrm{kg}$ of human weight $)$ per week \\
\hline $\mathrm{Pb}$ & $25^{\mathrm{a}}$ \\
$\mathrm{Cu}$ & $3500^{\mathrm{a}}$ \\
$\mathrm{Cd}$ & $7^{\mathrm{a}}$ \\
$\mathrm{Hg}$ & $1,6^{\mathrm{b}}$ \\
$\mathrm{Zn}$ & $7000^{\mathrm{a}}$ \\
\hline
\end{tabular}

Information: a. JEFCA in FAO/WHO (2004); b. WHO in Zazouli et al. (2006) 


\section{HASIL DAN PEMBAHASAN}

Bersamaan dengan pengambilan sampel kerang lokan, juga dilakukan pengukuran parameter kualitas air. Adapun hasil pengukuran parameter kualitas air pada tiga stasiun pengambilan sampel dapat dilihat pada Table 2.

Hasil pengukuran didapat bahwa suhu pada setiap stasiun menunjukkan kondisi masih normal dan baik. Islami (2013) menyebutkan bahwa kerang dapat hidup pada kisaran suhu $20^{\circ} \mathrm{C}$ sampai $35^{\circ} \mathrm{C}$. Kisaran $\mathrm{pH}$ disetiap stasiun tidak berbeda secara signifikan, hal ini diperkuat oleh pernyataan Wijayanti (2007) yaitu, kelompok bivalvia dapat hidup pada kisaran $\mathrm{pH} 5,8$ - 8,3. Kandungan oksigen terlarut (DO) pada suatu perairan menunjukkan tingkat pencemaran lingkungan, hal ini sesuai dengan pernyataan Salmin (2005) yaitu, peran oksigen terlarut sebagai pengoksidasi dan pereduksi senyawa kimia beracun menjadi senyawa dengan bentuk lebih sederhana dan merubah sifat senyawa tersebut menjadi tidak beracun.

\section{Kandungan Logam Berat $(\mathrm{Pb}, \mathrm{Cu}$, $\mathrm{Hg}, \mathrm{As}, \mathrm{Cd}, \mathrm{Zn}$ ) pada Kerang Lokan}

Dalam proses kehidupan manusia, logam berat diperlukan dalam proses produksi sebuah industri (Adhani dan Husaini 2017), akan tetapi bila penggunaanya melebihi batas yang telah ditentukan maka logam-logam tersebut bersifat racun.

\section{Merkuri (Hg)}

Stasiun 1 (perairan Meureubo) tidak terdeteksi adanya logam merkuri (Hg) yang tercemar di dalam daging kerang lokan(Figure 2). Stasiun 2 dan 3 diketahui terjadinya pencemaran logam merkuri $(\mathrm{Hg})$ pada lingkungan perairan yang kemudian terakumulasi didalam organisme kerang lokan. Kandungan logam $\mathrm{Hg}$ tertinggi dimiliki oleh kerang lokan yang berasal dari perairan Ujong Baroh (Stasiun 2). Cemaran logam $\mathrm{Hg}$ bersumber dari tingginya aktivitas

Table 2 Water Quality Parameters

\begin{tabular}{cccc}
\hline \multirow{2}{*}{ Parameter } & \multicolumn{3}{c}{ Location } \\
\cline { 2 - 4 } & $\begin{array}{c}\text { Station I } \\
\text { Meurebo }\end{array}$ & $\begin{array}{c}\text { Station II } \\
\text { Ujong Baroh }\end{array}$ & $\begin{array}{c}\text { Station III } \\
\text { Samatiga }\end{array}$ \\
\hline Temperature $\left({ }^{\circ} \mathrm{C}\right)$ & 30 & 30 & 29 \\
pH & 6.3 & 5.1 & 5.5 \\
DO $(\mathrm{mg} / \mathrm{L})$ & 3.3 & 7 & 6.5 \\
Substrate & Muddy sand & Muddy sand & Muddy sand \\
\hline
\end{tabular}

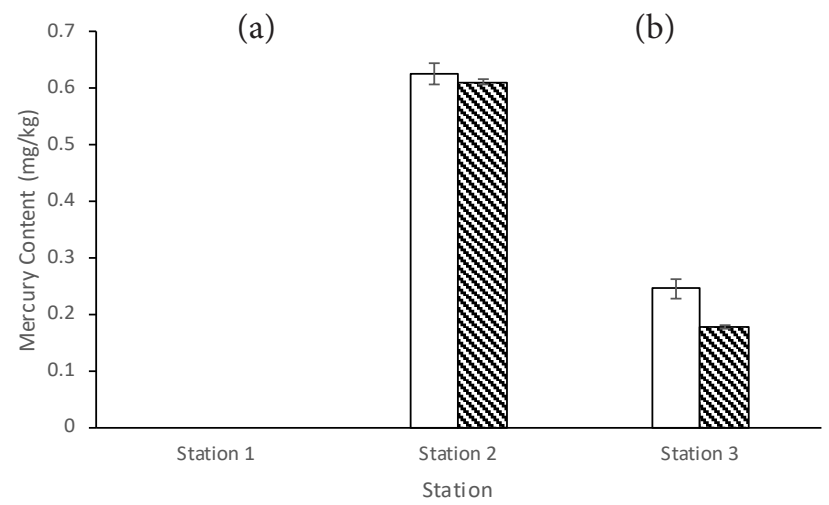

Figure 2 Mercury (Hg) in Geloina erosa from West Aceh Coastal; ( $\square$ ) Raw; (N) Boiled. 
kapal nelayan di perairan Ujong Baroh, biasanya tejadi pembuangan solar kapal ke perairan. Chen et al. (2012) menyatakan jumlah $\mathrm{Hg}$ yang terdeteksi pada sedimen suatu perairan menunjukkan tingkat polusi bagi badan air perairan tersebut. Azhar et al. (2012) menyatakan bahwa limbah buangan kapal nelayan yaitu berupa solar dan buangan limbah dari irigasi sawah yaitu berupa pupuk pertanian mempengaruhi keberadaan logam di perairan.

\section{Tembaga (Cu)}

Kandungan Tembaga $(\mathrm{Cu})$ pada daging kerang lokan dari perairan Aceh Barat dapat dilihat pada Figure 3.

Berdasarkan Figure 3, diketahui bahwa daging kerang lokan dari ketiga perairan positif mengandung Logam $\mathrm{Cu}$. Kandungan $\mathrm{Cu}$ tertinggi terdapat pada daging kerang lokan asal perairan Samatiga (stasiun 3). Sumber logam $\mathrm{Cu}$ diketahui berasal dari pencemaran kegiatan pertanian oleh masyarakat sekitar, selain itu bias juga bersumber dari aktivitas vulkanik (Doelsch et al. 2006). Proses perebusan yang dilakukan pada sampel daging kerang lokan diketahui dapat menurunkan kandungan logam berat Tembaga $(\mathrm{Cu})$ sebesar 40-80\%. Hal ini menunjukkan bahwa Tembaga $(\mathrm{Cu})$ mudah dirusak atau dipecah dengan proses pengolahan suhu tinggi. Suaniti (2007) menyatakan penurunan konsentrasi $\mathrm{Cu}$ disebabkan oleh terlepasnya ikatan kompleks logam protein akibat suhu tinggi, sehingga ion-ion logam tersebut keluar dari dalam daging kerang.

\section{Seng (Zn)}

Penyebaran seng dalam lingkungan cukup luas dapat ditemukan dalam air, udara dan organisme hidup. Seng dalam keadaan tertentu mempunyai toksisitas yang rendah pada manusia tetapi mempunyai toksisitas yang tinggi pada ikan sehingga standar suplay air untuk keperluan domestik kandungan sengnya maksimum $5 \mathrm{mg} / \mathrm{L}$. Toksisitas seng sangat dipengaruhi oleh beberapa faktor lingkungan, diantaranya temperatur dan tingkat kelarutan $\mathrm{O}_{2}$. Kandungan Seng $(\mathrm{Zn})$ pada daging kerang lokan dari perairan Aceh Barat dapat dilihat pada Figure 4.

Berdasarkan Figure 4, diketahui bahwa daging kerang lokan dari ketiga stasiun positif mengandung Seng (Zn), dimana daging kerang lokan asal perairan Ujong Baroh merupakan stasiun dengan kandungan Seng

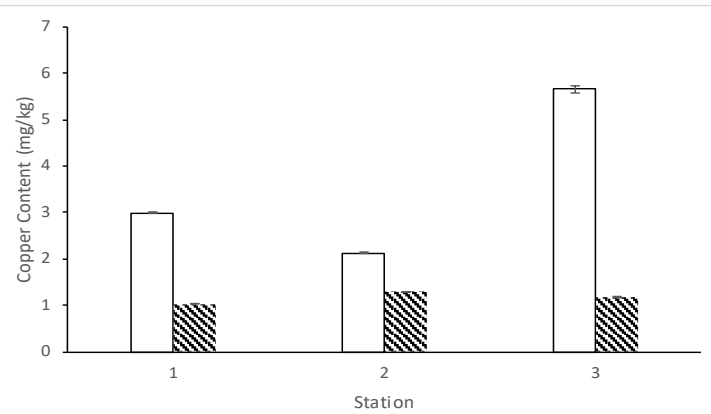

Figure 3 Copper (Cu) Geloina erosa from West Aceh coastal; (i: Raw; (N)Boiled.

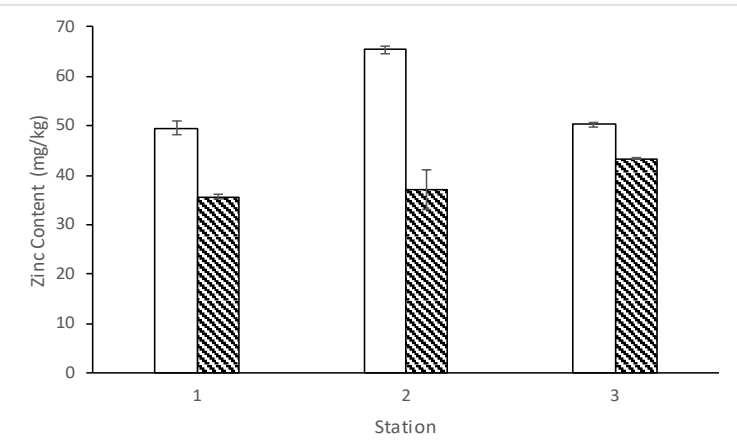

Figure 4 Zinc (Zn) Geloina erosa from West Aceh coastal; (푸) Raw; (N)Boiled. 
(Zn) tertinggi. Konsentrasi logam $\mathrm{Zn}$ diduga berasal dari limbah dari kegiatan masyarakat; misalnya penggunaan pupuk kimia, pipa air yang sudah korosif, dan penggunaan detergen (Tarigan et al. 2003). Logam tersebut akan membentuk ion ketika bercampur dengan air sehingga mudah terserap dalam sedimen maupun organisme, sehingga konsentrasi logam berat $\mathrm{Zn}$ dalam air akan turut memengaruhi konsentrasi logam berat pada sedimen maupun organisme di perairan tersebut (Putri et al. 2015).

Berdasarkan BPOM No. 03725/B/SK/ VII/89 batas maksimum cemaran logam Zn dalam makanan khusunya untuk ikan dan hasil olahan lainnya yaitu sebesar $100 \mathrm{mg} /$ kg. Dari data yang diperoleh pada Figure 4, konsentrasi logam Zn dalam kerang lokan belum melampaui batas yang ditetapkan. Deswati et al. (2013) menginformasikan bahwa konsumsi Zn dalam jumlah lebih akan menyebabkan diare, diare, demam, anemia, serta gangguan pada sistem reproduksi.

Logam berat yang mencemarri lingkungan perairan dipindahkan dari badan airnya melalui tiga tahapan proses, yaitu penggendapan, adsorbs, dan absorbi oleh biota perairan (Siaka 2008). Cemaran yang masuk ke peraiaran terlebih dahulu akan mengendap dalam sedimen (Marasabessy et al. 2010), sehingga konsentrasi bahan pencemar di dalam sedimen lebih tinggi. akan tetapi adanya kontaminasi logam $\mathrm{Zn}$ yang terjadi di perairan ini akan bertambah seiring dengan berjalannya waktu, sehingga perlu dilakukan pengelolaan lingkungan perairan akibat aktivitas masyarakat dan industri.

\section{Maximum Tolerable Intake Kerang Lokan}

Maximum Tolerable Intake menunjukan angka batas maksimum suatu zat dapat dikonsumsi dalam waktu satu minggu tanpa menimbulkan efek merugikan terhadap kesehatan. Berat maksimum jaringan lunak kerang lokan yang dikonsumsi tiap minggu ditampilkan dalam Table 2.

Nilai MWI logam Hg kerang lokan stasiun 1 dan stasiun 2 yang aman untuk dikonsumsi manusia dengan rata-rata berat badan $50 \mathrm{~kg}$ yaitu 0,0008 gram. Apabila konsumsi kerang lokan tersebut melebihi nilai MWI, maka logam $\mathrm{Hg}$ akan bersifat sebagai racun di dalam tubuh manusia. Menurut Cullen et al. (2005) keracunan $\mathrm{Hg}$ dapat menyebabkan gangguan pada pertumbuhan, fungsi otak, dan juga disfungsi hati maupun ginjal dan menurut Juberg et al. (1997) dapat menggangu sistem reproduksi. Batas aman mengkonsumsi kerang lokan yang mengandung merkuri $(\mathrm{Hg})$ untuk orang dengan berat badan $50 \mathrm{~kg}$, yaitu maksimal $0,131 \mathrm{~kg}$ per minggu untuk kerang lokan dari perairan Ujong Baroh, sedangkan kerang lokan dari perairan Samatiga maksimal sebanyak $0,452 \mathrm{~kg}$ per minggu.

Batas aman mengkonsumsi kerang lokan yang mengandung logam berat $\mathrm{Cu}$ untuk orang dengan berat badan $50 \mathrm{~kg}$, yaitu sebanyak sebanyak 170,018 g per minggu untuk kerang lokan dari perairan Meureubo, 135,522 kg

Table 2 The Maximum Weight Limits of lokan clam consumption per Week (for individuals with $50 \mathrm{~kg}$ average weight)

\begin{tabular}{lcccc}
\hline Location & Heavy Metal & MWI (gr) & Ct $(\mathrm{gr} / \mathrm{kg})$ & MTI $(\mathrm{kg})$ \\
\hline \multirow{3}{*}{ Station 1 } & $\mathrm{Hg}$ & 0.00008 & 0 & 0 \\
& $\mathrm{Cu}$ & 0.175 & 0.0010293 & 170.018 \\
& $\mathrm{Zn}$ & 0.35 & 0.0356187 & 9.826 \\
\multirow{5}{*}{ Station 2 } & $\mathrm{Hg}$ & 0.00008 & 0.0006111 & 0.131 \\
& $\mathrm{Cu}$ & 0.175 & 0.0012913 & 135.522 \\
& $\mathrm{Zn}$ & 0.35 & 0.0370791 & 9.439 \\
\multirow{5}{*}{ Station 3 } & $\mathrm{Hg}$ & 0.00008 & 0.000177 & 0.452 \\
& $\mathrm{Cu}$ & 0.175 & 0.001173 & 149.190 \\
& $\mathrm{Zn}$ & 0.35 & 0.043378 & 8.069 \\
\hline
\end{tabular}


per minggu kerang lokan dari Perairan Ujong Baroh dan dari 149,190 kg per minggu untuk kerang lokan dari Perairan Samatiga. Menurut Darmono (2001) dalam Widaningrum et al. (2007) kelebihan akumulasi logam $\mathrm{Cu}$ di dalam tubuh manusia dapat menyebabkan gejala keracunan seperti mual, sakit perut, muntah, diare, serta dapat mengakibatkan kematian.

Batas aman mengkonsumsi kerang lokan yang mengandung logam berat $\mathrm{Zn}$ untuk orang dengan berat badan $50 \mathrm{~kg}$, yaitu sebanyak 9,826 kg per minggu untuk kerang lokan dari perairan Meureubo, 9,439 kg per minggu untuk kerang lokan dari Perairan Ujong Baroh, dan 8,069 kg per minggu untuk kerang lokan dari Perairan Samatiga.

Pemilihan batas maximum tolerable intake (MTI) berdasarkan nilai MTI terkecil, hal ini sesuai dengan pernyataan Hidayah et al. (2014) bahwa pemilihan MTI dengan nilai terkecil dari jenis residu logam berat bertujuan untuk menghindari terjadinya pengendapan logam dalam tubuh yang dapat menyebabkan kematian pada manusia. Oleh karena itu, berdasarkan hasil penelitian MTI, logam $\mathrm{Hg}$ menjadi batas aman konsumsi kerang lokan dari perairan Aceh Barat, khususnya perairan Ujong Baroh dan Samatiga yang terdeteksi mengandung logam $\mathrm{Hg}$.

\section{KESIMPULAN}

Kerang lokan yang berasal dari Perairan Aceh Barat diketahui mengandung beberapa jenis logam berat, yaitu dari Meureubo (stasiun I) terdeteksi mengandung logam berat $\mathrm{Cu}$ dan $\mathrm{Zn}$, kerang dari Perairan Ujong Baroh (stasiun II) terdeteksi mengandung logam berat $\mathrm{Hg}, \mathrm{Cu}, \mathrm{Cd}$, dan $\mathrm{Zn}$, dan dari Perairan Samatiga (stasiun III) terdeteksi mengandung logam berat $\mathrm{Hg}, \mathrm{Cu}$, dan $\mathrm{Zn}$. Batas maksimal konsumsi daging kerang lokan untuk berat tubuh rata-rata $50 \mathrm{~kg}$ yaitu $0,131 \mathrm{~kg}$ per minggu.

\section{DAFTAR PUSTAKA}

Adhani R, Husaini. 2017. Logam Berat Sekitar Manusia. Banjarmasin (ID): Lambung Mangkurat University Press.

[APHA] American Public Health Association. 1992. Standard Method for The
Examination of Water and Wastewater. $18^{\text {th }}$ edition. Washington (US): American Public Health Association.

Azhar H, Widowati I, Suprijanto J. 2012. Studi kandungan logam berat $\mathrm{Pb}, \mathrm{Cu}$, $\mathrm{Cd}, \mathrm{Cr}$ pada kerang simping (Amusium pleuronectes), air dan sedimen di Perairan Wedung, Demak serta analisis maximum tolerable intake pada manusia. Journal of Marine Research. 1(2): 35-44.

Chen CW, Chen CF, Dong CD. 2012. Contamination and potential ecological of mercury in sediments of Kaohsiung river mouth, Taiwan. International Journal of Envitonmental Science and Development. 3(1): 66-71.

Cullen G, Dines A, Kolev S. 2005. Lead IPCS INTOX-Data bank. National Poison Information Service, London (UK).

Davis SR, Cousins RJ. 2000. Metallothionein expresion in animals: A physiological perspective on function. Journal of Nutrition. 130(5):1085-1088.

Deswati, Suyani H, Chairini N. 2013. Studi optimasi penentuan seng secara voltammetry stripping adsorptive (AdSV). Jurnal Kimia Unand. 2(1):98106.

[DKP] Dinas Kelautan dan Perikanan Aceh Barat. 2017. Data Perairan Aceh Barat.

Doelsch, E., V. Van de Kerchove, H.S. Macary. 2006. Heavy metal content in soils of reunion (Indian Ocean). Geoderma, 134 (1-2): 119-134.

Edwarsyah. 2017. Kuantitas kandungan logam berat dan minyak solar di estuaria Krueng Cangkoi Kabupaten Aceh Barat. Journal of Acta Aquatica. 4(2): 83-87.

Hidayah AM, Purwanto, Soeprobowati TR. 2014. Biokonsentrasi faktor logam berat $\mathrm{Pb}, \mathrm{Cd}, \mathrm{Cr}$, dan $\mathrm{Cu}$ pada ikan nila (Oreochromis niloticus Linn.) di karamba Danau Rawa Pening. Bioma: Berkala Ilmiah Biologi. 16(1): 1-9.

Islami MM. 2013. Pengaruh suhu dan salinitas terhadap bivalvia. Jurnal Oseana. (2): 1-10.

Irawan B, Bintal A, Thamrin. 2015. Analisis kandungan logam berat $\mathrm{Cu}, \mathrm{Pb}$ Dan Zn pada air, sedimen, dan bivalvia di Perairan Pantai Utara Pulau Bengkalis. 
Jurnal Dinamika Lingkungan Indonesia. 2(1): 40-51.

Juberg, DR, Kleiman CF, Kwan SC. 1977. Lead and human health. American Council on Science and Health. New York (US): American Council on Science and Health. Marasabessy MD, Edward, Valentin FL. 2010. Pemantauan kadar logam berat dalam air laut dan sedimen di perairan Pulau Bacan, Maluku Utara. Jurnal Sains. 14(1): 32-38.

Munandar, Alamsyah A. 2016. Kajian kandungan logam berat merkuri $(\mathrm{Hg})$ pada kerang air tawar Anodonta sp. di kawasan hilir sub das Krueng Meureubo, Aceh Barat. Jurnal Perikanan Tropis. 3(1): 11-19.

Palar H. 2004. Pencemaran dan Toksikologi Logam Berat. Jakarta (ID): Rineka Cipta.

Putri LSE, Prasetyo AD, Arifin Z. 2012. Green mussel (Perna viridis) as bioindicator of heavy metals pollution at Kamal Estuary, Jakarta Bay, Indonesia. Journal of Environmental Research and Development. 6(3): 389-396.

Salmin. 2005. Oksigen terlarut (DO) dan kebutuhan oksigen biologi (BOD) sebagai salah satu indikator untuk menentukan kualitas perairan. Jurnal Oseana. 30(3): 21-26.

Setiawan H. 2013. Akumulasi dan distribusi logam berat pada vegetasi mangrove di perairan pesisir Sulawesi Selatan. Jurnal Ilmu Kehutanan. 7(1): 12-24.
Siaka IM. 2008. Korelasi antara kedalaman sedimen di Pelabuhan Benoa dan konsentrasi logam berat $\mathrm{Pb}$ dan $\mathrm{Cu}$. Jurnal Kimia. 2(2): 61-70.

Suaniti M. 2007. Pengaruh edta dalam penentuan kandungan timbal dan tembaga pada kerang hijau (Mytilus viridis). Jurnal Ecotrophic. 2(1): 1-7.

Turkmen M, Turkmen A, Tepe Y. 2008. Metal contaminations in five fish species from black, marmara, aegean, and Mediteranean Sea, Turkey. Journal of Chilean Chemical Society. 53(1): 14351439.

Vallee B, Ulmer DD. 1972. Biochemical effect of mercury, cadmium and lead. Annual Review of Biochemistry. 41(10): 91-128.

Warni D, Karina S, Nurfadillah N. 2017. Analisis logam $\mathrm{Pb}, \mathrm{Mn}, \mathrm{Cu}$, dan $\mathrm{Cd}$ pada sedimen di pelabuhan Jetty Meulaboh, Aceh Barat. Jurnal Ilmiah Mahasiswa Kelautan dan Perikanan Unsyiah. 2(2): 246-253.

Wijayanti H. 2007. Kajian kualitas perairan di Pantai Kota Bandar Lampung berdasarkan komunitas hewan makrobenthos. [Tesis]. Bogor (ID): Institut Pertanian Bogor.

Widaningrum, Miskiyah, Suismono. 2007. Bahaya kontaminasi logam berat dalam sayuran dan alternatif pencegahan cemarannya. Buletin Teknologi Pascapanen Pertanian. 3: 16- 27. 